\title{
PROCEEDINGS OF THE THIRD ANNUAL MEETING OF THE PALEONTOLOGICAL SOCIETY, HELD AT WASHINGTON, D. C., DECEMBER 28, 29, AND 30, 1911
}

\section{R. S. BASSLER, Secretary}

\section{CONTENTS}

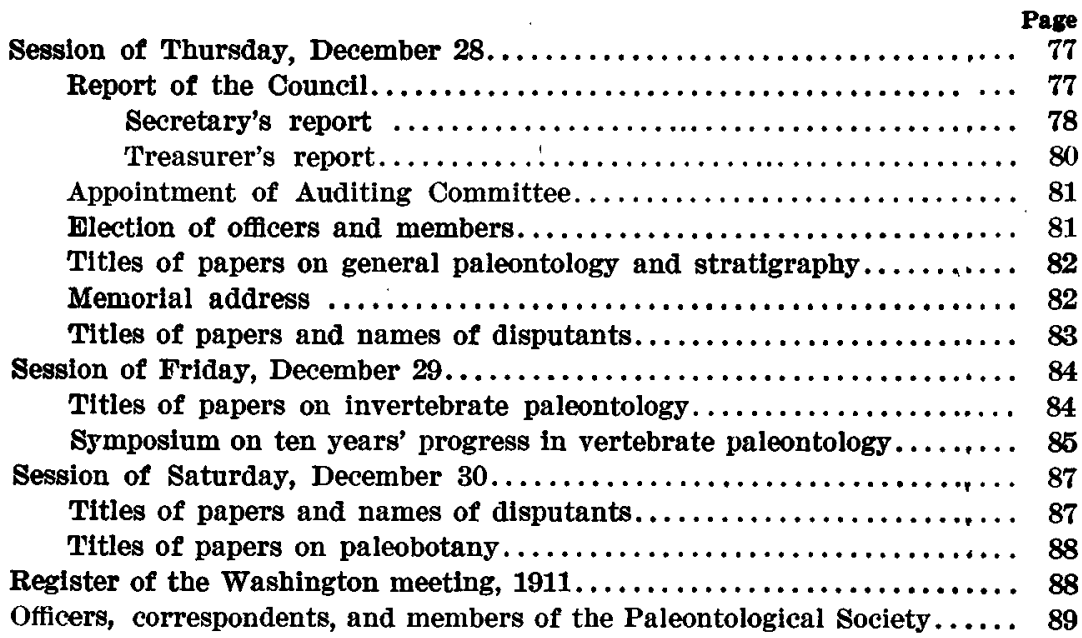

\section{Session of Thursday, December 28, 1911}

The opening session of the Society was called to order at 10 o'clock, Thursday morning, December 28, 1911, by Vice-President Arthur Hollick, in the new National Museum. Dr. Charles D. Walcott, Secretary of the Smithsonian Institution, welcomed the Society to Washington and made an informal address on the beginnings and progress of Paleontology in America.

The report of the Council, the first matter of business, was then presented.

\section{REPORT OF THE COUNCIL}

\section{To the Paleontological Society in Third Annual Meeting assembled:}

The regular annual meeting of the Council was held at Pittsburgh on the adjournment of the Society December 29, 1910. Since this meeting all business of the Society has been arranged by correspondence. The details of administration for the third year of the Society's existence are given in the following reports of officers: 
SWCRETARY'S REPOR'T

\section{To the Council of the Paleontological Society:}

The proceedings of the second annual meeting of the Society, held at Pittsburgh, Pennsylvania, December 28-29, 1910, have been recorded in Volume XXII, pages 85-102, of the Bulletin of the Geological Society of America. Copies of this as well as of the other publications of the Society have been sent to every member.

At the annual meeting of the Council and by correspondence the. list of officers for 1912 was prepared and, according to the By-Laws, forwarded to the members on March 19, 1911. It was then also announced that the third annual meeting of the Society would occur in Washington, D. C., beginning December 28, 1911, at the invitation of the Smithsonian Institution, extended through the Secretary, Dr. Charles D. Walcott.

During the past year the Society has lost one member by death, Prof. Samuel Calvin. Two resignations have become effective. The names of the eleven members elected at the Pittsburgh meeting have been added to the list and all of them have completed their membership according to rule. The present enrollment of the Society is 124. Twelve candidates are before the Society for election and thirteen applications are under consideration by the Council.

Following the authorization of the Council, Prof. J. C. Merriam organized a Pacific Coast section of the Paleontological Society, which held its first meeting last March. Professor Merriam reports a very successful meeting, with fourteen papers presented and about thirty in attendance.

At the last meeting of the Society a committee was appointed to prepare a report on securing a change in the classification of the freight rates on fossils. The chairman of this committee, Dr. W. J. Holland, has submitted the following:

\section{Report of Committee Appointed at the Pittsburgh Meeting to Secure a Change of Classification in Freight Rates on Fossils}

I desire to report that, as chairman of the committee appointed to secure a reduction in the rates which have hitherto been charged on fossils, immediately after the adjournment of the meeting I took the matter up with Mr. F. S. Holbrook, of the Official Classification Committee in New York, and with the officers of the Transcontinental Freight Association and the Southern Classification Committee. I was seconded in my efforts by Mr. Joseph Wood, the president of the Pennsylvania lines West, and other officers of the Pennsylvania Railroad, who extended to me every courtesy. As a result, the Ofhcial Classification in New York, which covers all of the roads east of the Mississippl River, acceded to my request, and by consulting their rate sheets the members of the Society will see that fossils extracted from rock, boxed, 
are rated as first class; fossils in rock, less than carloads, are rated as second class, and in carloads of 30,000 pounds they are rated fourth class. The Western Classification Committee has supplemented its classification by the enactment of the following, to take effect after December 15, 1911 :

Fossil specimens:

In the rock:

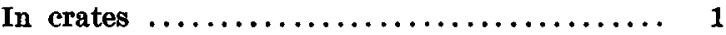

In barrels or boxes.................... 2

In packages or loose, carload, minimum weight 24,000 pounds $\ldots \ldots \ldots \ldots \ldots \ldots \ldots \ldots \ldots, 4$

Not in the rock:

In barrels or boxes................... 1

In packages named, carload, minimum weight 20,000 pounds $\ldots \ldots \ldots \ldots \ldots \ldots \ldots \ldots \ldots$. 3

Fossil casts or reproductions:

Cement or plaster :

In barrels or boxes.................... 1

In packages named, straight or mixed, carload, minimum weight 20,000 pounds.......... 3

Your committee apparently has not labored in vain. The rates accorded by the Western Classification Committee are slightly more favorable, as will be observed, than are accorded by the Official Classification in New York, representing the roads east of the Mississippi. Your committee would be happy, however, if all the railways could be led to feel, as he is aware some of the Western railroads do, that museums and colleges are properly regarded, and have been judicially held to be regarded as "charitable institutions," and that therefore the forwarding of scientific specimens free of charge might be undertaken without violation either of the spirit or letter of the regulations adopted by the Interstate Commerce Commission.

All of which is respectfully submitted.

(Signed)

\section{W. J. HoLLAND,}

Committee.

At the last election for Fellows in the Geological Society of America, E. B. Branson and Burnett Smith, members of the Paleontological Society, proposed by the Council, were elected to Fellowship. Walter Granger, Lawrence M. Lambe, E. S. Riggs, R. Anderson, Frank Springer, and C. R. Stauffer, of our Society, were also elected to Fellowship in the Geological Society of America on the nomination of individual Fellows of the two Societies.

The members of the Council representing Vertebrate Paleontology suggested a Symposium for the Washington meeting, entitled "Ten Years' Progress in Vertebrate Paleontology," and proposed a list of the 
special subjects to be considered. The Council approved their suggestion and the program printed on a following page was arranged.

Respectfully submitted.

Washington, D. C., December 20, 1911.
R. S. BASSLER, Secretary.

\section{Treasurer's RePorT}

\section{To the Council of the Paleontological Society:}

The Treasurer reports a prosperous year, dues both current and in arrears having been received from every member of the Society but five.

Such bills as were presented to the Treasurer were duly endorsed by the President and promptly paid. They were in excess of the annual expenditures, as up to the time of the present incumbent practically no bills had been presented against the Society, so that this year's outlay represents the entire expenses of the organization to date.

The Treasurer desires instructions on two points: whether or no he shall execute the bond of one thousand dollars $(\$ 1,000)$ as required by the Constitution, and as to the advisability of insuring the Society's funds against the possibility of loss other than by malfeasance in office.

The funds at present standing in the Treasury, deposited in the name of the Society in the Second National Bank of New Haven, Connecticut, are as follows:

\section{RECEIPTS}

Balance recelved from retiring Treasurer, Dr. W. D. Matthew $\$ 141.91$

Dues of members (with arrears) for 1911 ( $\$ 186.00$ less $\$ 3.00$ overcharge returned) $\ldots \ldots \ldots \ldots \ldots \ldots \ldots \ldots \ldots \ldots \ldots \ldots . \ldots 183.00$

EXPENDITURES

Treasurer's office :

Postage $\ldots \ldots \ldots \ldots \ldots \ldots \ldots \ldots \ldots \ldots \ldots \ldots \ldots \ldots \ldots \ldots \ldots$
Stationery $\ldots \ldots \ldots \ldots \ldots \ldots \ldots \ldots \ldots \ldots \ldots \ldots \ldots \ldots \ldots \ldots$
$\mathbf{\$ 3 . 0 0}$

Secretary's office:

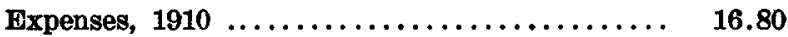

Secretary's allowance, $1910 \ldots \ldots \ldots \ldots \ldots \ldots \ldots .50 .00$

Geological Society of America, printing, stationery, postage, and clerical work (\$43.95 less rebate of $\$ 2.25) \ldots \ldots \ldots \ldots$

Geological Society of America, Proceedings Paleontological Society, excess separates.................... 18.50

- $\$ 141.84$

Balance on hand December $21,1911 \ldots \ldots \ldots \ldots \ldots \ldots \ldots \ldots \ldots \ldots$

Respectfully submitted.

$\$ 324.91$

Richard S. LuLL,

New Haven, Connecticut, December, 1911.

Treasurer. 


\section{APPOINTMENT OF AUDITING COMMITTEE}

The chair then appointed A. W. Grabau and T. W. Stanton as a committee to audit the Treasurer's accounts. In response to the Treasurer's inquiry regarding a bond of $\$ 1,000$, a motion by John M. Clarke, duly seconded, was adopted by the Society to the effect that the funds in the Treasury were not sufficient at present to require such a bond of the Treasurer.

\section{ELEOTION OF OFFICERS AND MEMBERG}

The declaration of the vote for officers for 1912 and for members was announced by the Secretary as follows:

\section{OFFICERS FOR 1918 \\ President:}

David WhIte, Washington, D. C.

First Vice-President:

J. C. Merriam, Berkeley, Cal.

Second Vice-President:

Rudolf Ruedemans, Albany, N. Y.

Third Vice-President:

E. W. BERRY, Baltimore, Md.

Secretary:

R. S. BASSLER, Washington, D.C.

Treasurer:

Riohard S. LuLl, New Haven, Conn.

\section{Editor:}

Charles R. Eastman, Pittsburgh, Pa.

\section{MEMBERS}

Harvey Bassler, Johns Hopkins University, Baltimore, Maryland. CharLes Butts, U. S. Geological Survey, Washington, D. C. Will Edwin Grane, Swissvale P. O., Pittsburgh, Pennsylvania. Judia ANNa Gardner, Johns Hopkins University, Baltimore, Maryland. F. C. Grame, Geological Survey of Missouri, Rolla, Missouri. E. C. JEmrRaY, Harvard University, Cambridge, Massachusetts. Clara Gould Mark, Westerville, Ohio. MaURIce G. Ment, University of Chicago, Chicago, Illinois. 
Rector Duval Mrscer, U. S. Geological Survey, Washington, D. C. JAMEs D. NarRaway, Department of Justice, Ottawa, Canada. Herrick East Wilson, University of Chicago, Chicago, Illinois. Wrutram James Wirson, Geological Survey of Canada, Ottawa, Canada.

Titles of PaPers on general Paleontology aNd stratigraphy

After various announcements by the chair of arrangements for the meetings of the Society and other matters, the reading of the scientific papers, beginning with "General Paleontology and Stratigraphy," was taken up.

\section{PHYAICAL OONDITIONS UNDER WHIOH ORGANIC AND OHEMIOALLY PREOIPITATED LIMESTONES ARE FORMED}

BY T. WAYLAND VAUGHAN

Read by the author from manuscript; 15 minutes.

COASTAL PLAIN INVESTIQATIONS CONDUCTED BY THE UNITED STATES AND STATE GEOLOGICAL SURTEYS

BY T. WAYLAND VAUGHAN

Presented without manuscript; illustrated with lantern slides and maps; 20 minutes. This paper included a statement by L. W. Stephenson, read from manuscript by the writer.

STATE OF OUR KNOWLEDGE OF THE MIDDLE AMERIUAN TERTIARY

BY WM. H. DALL

Presented from manuscript; 20 minutes.

REMARKS ON THE GEOLOGIO SEOTION OF THE ISTHMUS OF PANAMA

BY D. F. MAC DONAID

Presented without manuscript; illustrated with drawings; 20 minutes. Discussed by T. Wayland Vaughan and Ernst Howe.

At $12.30 \mathrm{p} . \mathrm{m}$. the Society adjourned for luncheon, convening again at 2 p. m., with Vice-President Stuart Weller in the chair, when the papers on "General Paleontology and Stratigraphy" were continued, preceded by a memorial on Prof. Samuel Calvin.

\section{MEMORIAL ADDRESS}

Professor Weller spoke of the Society's loss by death during the year of Professor Calvin and reviewed his work in science, and especially his

Introduced by T. Wayland Vaughan. 
influence on his students. A memoir of Professor Calvin will be presented in the Bulletin of the Geological Society of America.

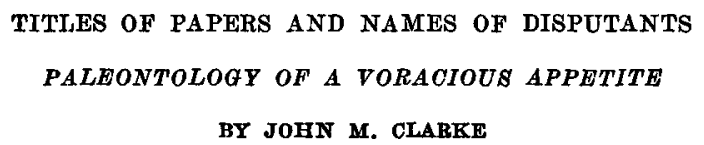

Presented by the author without manuscript; illustrated with lantern slides; 10 minutes. Discussed by A. W. Grabau and H. S. Williams.

CORRELATION OF THE PALEOZOIO FAUNAS OF THE EASTPORT QUADRANGLE, MAINE

BY HENRY SHATER WILITAMB

Read from manuscript; 20 minutes. Discussed by H. M. Ami, J. M. Clarke, David White, and E. S. Bastin.

\section{FOSSILIFEROUS CONGLOMERATES}

BY A. W. GRABAD

Presented without manuscript; illustrated by sketches; 10 minutes. Discussed by R. Ruedemann, G. W. Stose, J. M. Clarke, C. A. Reeds, T. W. Stanton, W. T. Lee, Joseph Barrell, and Sidney Paige, with reply by the author.

ORISKANY SANDSTONES OF ONTARIO

BY CLINTON B. STAUFFER

Presented without manuscript; 10 minutes. Discussed by W. A. Parks and J. M. Clarke.

\section{TO WHAT PART OF THE RICHMOND DOES THE MEDINA OF ONTARIO CORRESPOND \\ BY A. F. FOLRSTH}

Presented without manuscript; 15 minutes. Discussed by A. W. Grabau, E. R. Cumings, E. O. Ulrich, and the author.

\section{NOTES ON THE DICTYONEMAS OF NEW BRUNSWIOK}

BY F. F. HAHN ${ }^{2}$

Read from manuscript and illustrated with drawings; 10 minutes. Discussed by R. Ruedemann.

\footnotetext{
- Introduced by A. W. Grabau.
} 
BY W. A, PARKS

Presented without manuscript; illustrated with lantern slides and specimen; 10 minutes. Discussed by A. W. Grabau.

At 5 o'clock the Society adjourned for the day.

Thursday evening the members of the Society took part in the Annual Dinner with the Fellows of the Geological Society of America.

\section{Session of Friday, December 29.}

Friday morning the Society was called to order at 10 o'clock by President Scott, who announced that the morning would be devoted to the papers on Invertebrate Paleontology, while the Symposium papers would be read during the afternoon session.

W. D. Matthew moved that the incoming Council be instructed to designate a bank of deposit for the Treasurer's funds; motion seconded and passed.

The Auditing Committee then reported that the accounts of the Treasurer were found to be in good shape.

\section{TITLES OF PAPERS ON INVERTEBRATE PALEONTOLOGY}

DEVELOPMENT OF THE MONTIODLIPOROIDS

BY IDAAR R. OUMTNGS

Presented without manuscript; illustrated with sketches; 20 minutes. Discussed by R. S. Bassler and J. M. Clarke.

MIDDLE OAMBRIAN ORUSTAOEANS FROM BRITISH COLUMBIA

BY CHARLES D. WALCOTT

Presented without manuscript; illustrated with lantern slides and specimens; 20 minutes. Discussed by J. M. Clarke.

\section{THE OZARKIAN FAUNA}

BY Fi. O. ULRTCH

Presented without manuscript; illustrated with lantern slides; 20 minutes. Discussed by C. D. Walcott, Charles Butts, A. W. Grabau, H. M. Ami, L. D. Burling, and E. O. Ulrich. 
At 12.30 the Society adjourned for luncheon, convening at $2 \mathrm{p} . \mathrm{m}$. for the reading of the Symposium papers.

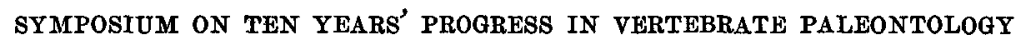

The following papers, most of which are published as a brochure of volume 23 , were then presented:

SOUTH AMERICAN MAMMALS

BY WM. B. SCOTT

Read from manuscript. Discussed by W. D. Matthew.

AFRIOAN MAMMALS

BY W. D. MATTHEW

Read from manuscript. Discussed by H. F. Osborn and W. B. Scott. PERISBODAOTYLA

BY $J$. W. GIDLEY

Read from manuscript. Discussed by H. F. Osborn and W. I. Matthew.

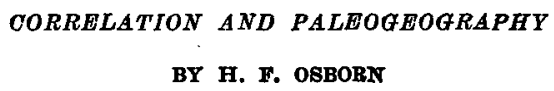

Presented without manuscript. Discussed by W. D. Matthew and W. J. Sinclair.

\title{
CARNIVORA AND RODENTIA
}

BY W. D. MATTHEW

Read from manuscript.

\author{
MARINE MAMMALS \\ BY F. W. TRUE
}

Read from manuscript. Discussed by W. B. Scott.

CRETACEOUS DINOSAURS

BY R. 8. LULr.

lead from manuscript by the author.

\section{PRE-CRETAOEOUS DINOSAURS}

BY W. J. HOLLAND

Read in the absence of the author by R. S. Lull. Discussed by W. B. Scott.

Introduced by C. D. Walcott. 
CONTRIBUTIONS TO GEOLOGIC THEORY AND METHOD

BY W. J. SINCLAIR

Read from manuscript. Discussed by W. D. Matthew.

ARTIODACTYLA

BY O. A. PETERSON

Read in the absence of the author by W. J. Sinclair. Discussed by W. D. Matthew.

\section{PALEOZOIC FISHES}

BY BASHFORD DEAN

Read by C. R. Eastman. Discussed by W. B. Scott and L. D. Burling. MESOZOIC AND CENOZOIC FISHES

BY C. R. EASTMAN

Read from manuscript by the author. Discussed by W. B. Scott and L. D. Burling.

PRIMATES, MARSUPIALS, AND INSECTIVORES

BY W, K, GREGORY

Read in the absence of the author by W. D. Matthew. Discussed by W. B. Scott.

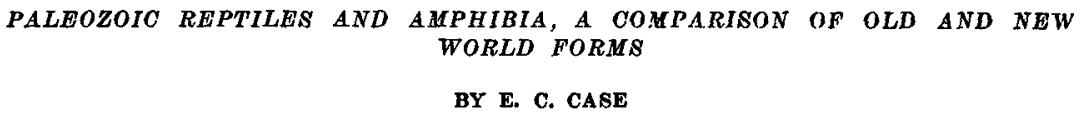

Read by member-elect M. G. Mehl.

\section{MARINE REPTILES \\ BY J. C. MERRIAM}

Read by W. J. Sinclair in the author's absence.

EVOLUTIONARY EVIDENCE

BY s. w. WILLISTON

Read by Stuart Weller.

At 5.30 the Society adjourned.

Friday evening the members of the Society attended the address of the retiring President of the Geological Society of America and took part in the smoker tendered to the Geological Society by the Geological Society of Washington at the Cosmos Club. 
Session of Saturday, December 30

Saturday morning the Society was called to order at 10 o'clock by VicePresident Matthew.

\section{TITLES OF PAPERS AND NAMES OF DISPUTANTS \\ NOTES ON DEVONIC CORALS \\ BY A. W. GRABAU}

Presented without manuscript; illustrated with sketches. Discussed by R. S. Bassler, with reply by the author.

\section{A FISH FAUNA FROM THE PENNSYLVANIAN OF WYOMING}

BY E. B. BRANSON

Presented without manuscript; illustrated with lantern slides; 15 minutes. Discussed by R. S. Bassler, W. D. Matthew, A. L. Miller, and C. R. Eastman, with remarks by the author.

\section{REMARKABLE SKELETON OF STEQOSAURUS}

BY C. W. GILMORE

Read from manuscript; illustrated with lantern slides; 20 minutes. Discussed by R. S. Lull and W. D. Matthew.

REMARKABLE SPECIMEN BELONGING TO THE GENUS EDESTUS

BY O. P. HAY

Presented without manuscript; illustrated with lantern slides; 15 minutes. Discussed by C. R. Eastman.

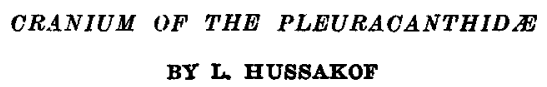

Read by title.

JURASSIC SAURIAN REMAINS INGESTED WITHIN FISH

BY C. R. EASTMAN

Delivered without manuscript; illustrated with photographs; 5 minutes.

ESTABLISHMENT OF FAUNAL DIVISIONS AMONG THE VERTEBRATES OF THE PLEISTOCENE

BY O. P. HAY

Delivered without manuscript; illustrated with lantern slides; 30 minutes. Discussed by W. D. Matthew.

I Introduced by R. S. Bassler. 
Vice-President Eastman then took the chair and the following paper was presented:

NOTES AND SLIDES OF THE UINTA BASIN EOCENE

BY E. B. BIGGS

Given without manuscript; illustrated with lantern slides; 20 minutes. TITLES OF PAPERS ON PALEOBOTANY

The two papers in Paleobotany listed below were then read by title on the request of their respective authors.

SOME INTERESTING NEW PLANTS FROM FLORISSANT, COLORADO

BT F. H. RNOWLTON

OHARACTERS OF CALAMITES INORNATUS DAWSON

BY DAVID WHITE

At 12.45 p. m. the Society adjourned.

Register of the Washington Meetina, 1911

HENRY M. AMI

ROBERT ANDERSON

RaIPH ARNold

R. S. BASSLER

J. W. BEEDE

E. W. BERRY

A. B. Bibbins

E. B. Branson

L. D. BuRling

JoHN M. Clarkis

William B. Clark

H. F. Cleland

E. R. Cominas

WM. H. DALL

C. R. Eastman

AUGUST F. Foerste

J. W. GIDLEY

Theo. M. Gilx

C. W. Gilmore

A. W. Grabau
$M E M B E R S$

Chris. A. Hartinaget

Arthur Hollick

JESSE E. HYDE

E. M. KINDLE

Edwin KirK

F. H. KNOWLTON

RICHARD S. LULL

Wendell C. Mansfield

W. D. Matthew

T. Poole Maynard

H. F. OsBorN

W. A. Parks

Charles S. Prosster

C. A. REEDS

E. S. RigGs

Rudolf RoedemanN

W. B. ScotT

WM. J. Sinclair

T. W. Stanton

C, R, Stauffer 
Charles K. Swartz

Mignon Talbot

M. W. TWITCHELL

E. O. UlRich

T. WAYLAND VAUghaN
Charles D. Walcott

StTART WELLER

David White

G. R. WIELAND

HeNRY S. Williams

MEMBERS-ELEOT

HARVEY BASSLER

Charles Butts

JULIA A. Gardner

F. C. Greene
E. C. JEFFREY

Clara G. Mark

Maurice G. Mehi.

R. D. MrsLer

H. E. WILsoN

OFFICERS, CORRESPONDENTS, AND MEMBERS OF' 'I'IIS

PALEONTOLOGICAL SOCIETY

OFFICERS FOR 1912

President:

David White, Washington, 1. C.

First Vice-President:

J. C. Merriam, Berkeley, Cal

Second Vice-President:

Rudolf RuedemanN, Albany, N. I.

Third Vice-President:

E. W. BERRY, Baltimore, Md.

Secretary:

R. S. BASSLER, Washington, D. C.

Treasurer:

Richard S. Lull, New Haven, Conn.

Editor:

Charles R. Eastman, Pittsburgh, Pa.

MEMBERSHIP, 1912

CORRESPONDENTS

Prof. Dr. A. C. NAthonst, Royal Natural History Museum, Stockholm, Sweden. Prof. Dr. E. KoKen, University of Tübingen, Tübingen, Germany.

S. S. Bucrman, Esq., Westfield, Thame, England.

Prof. Chardes DePeret, University of Lyon, Lyon (Rhone), France. 


\section{$M E M B E R S$}

Jose Guadalupe Aguilera, Ph. D., Instituto Geologico de Mexico, City of Mexlco, Mexico.

Truman H. Aldrich, M. E., 1739 P St. N. W., Washington, D. C.

Howry M. AMr, A. M., Geological and Natural History Survey of Canada, Ottawa, Canada.

Robert ANderson, U. S. Geological Survey, Washington, D. C.

RaIPH ARNoLd, Ph. D., 726 H. W. Hellman Bldg., Los Angeles, Cal.

RuFus M. BAga, Jr., Ph. D., Lawrence College, Appleton, Wis.

Edwin Hinckify Barbour, Ph. D., University of Nebraska, Lincoln, Neb.

RAY S. BassLer, Ph. D., U. S. National Museum, Washington, D. C.

Joshoa W. BeEDe, Ph. D., Indiana University, Bloomington, Ind.

B. A. Bensley, Ph. D., University of Toronto, Toronto, Canada.

EDWARD W. BerRY, Johns Hopkins University, Baltimore, Ma.

Arthur B. Bibbins, Ph. B., Woman's College, Baltimore, Md.

Walter R. Bilungs, 1250 Bank St., Ottawa, Canada.

Emil Böse, Ph. D., Instituto Geologico de Mexico, City of Mexico, Mexico.

E. B. Branson, Ph. D., University of Missouri, Columbia, Mo.

Barnum Brown, A. B., American Museum of Natural History, New York, N. Y.

Card Burck hardt, Ph. D., Instituto Geologico de Mexico, City of Mexico, Mexico.

Latrcaster D. Burlina, B. S., U. \$. National Museum, Washington, D. C.

Brmine C. Gase, Ph. D., University of Michigan, Ann Arbor, Mich.

F. C. Clark, Los Angeles, Cal.

Wimitam Bullock Clark, Ph. D., Johns Hopkins University, Baltimore, Ma.

John M. Clarke, A. M., State Hall, Albany, N. Y.

Herdman F. Cleuand, Ph. D., Williams College, Williamstown, Mass.

Harold J. Cook, Agate, Neb.

JoHs M. Coulter, Ph. D., University of Chicago, Chicago, Ill.

Edgar R. Cumings, Ph. D., Indiana University, Bloomington, Ind.

W. H. DALr, Sc. D., Snithsonian Institution, Washington, D. C.

Bashrord Dean, Ph. D., Columbia University, New York, N. Y.

Orvitre A. Derby, M. S., 80 Rua Visconde do Rio Branco, Sao Paulo, Brazll.

Eart Douglas, M. S., Carnegie Museum, Pittsburgh, Pa.

Charles R. Eastman, Ph. D., University of Pittsburgh, Pittsburgh, Pa.

George F. Eaton, Pl. D., 80 Sachem St., New Haven, Conn.

John Ererman, "Oakhurst," Easton, Pa.

Marcus S. FarR, Sc. D., Princeton University, Princeton, N. J.

August F. Foerste, Ph. D., 335 Salem Ave., Dayton, Ohio.

William M. Fontaine, A. M., University of Virginia, Charlottesville, Va.

E. I. Funlong, University of California, Berkeley, Cal.

Samuel Garman, Museum of Comparative Zoölogy, Cambridge, Mass.

G. S. Gester, Southern Pacific Railway, San Francisco, Cal.

Hugr Grbe, Peabody Museum, Yale University, New Haven, Conn.

J. W. Grduey, M. S., U. S. National Museum, Washington, D. C.

J. Z..GTr.Bert, A. M., Los Angeles High School, Los Angeles, Cal.

Theodore M. Girc, Ph. D., U. S. National Museum, Washlngton, D. C.

C. W. GILMore, B. S., U. S. National Museum, Washington, D. C.

Charles N. Gould, Ph. D., Norman, Okla. 
Amadeus W. Grabau, S. D., Columbia University, New York, N. Y.

Waumer Granger, American Museum of Natural History, New York Gity.

W. K. GregonY, Ph. D., American Museum of Natural History, New York City. Geobam W. Harper, Ph. D., 2139 Gilbert Ave., Cincinnati, Ohio.

Gilberat D. Harris, Ph. B., Cornell University, Ithaca, N. Y.

Chris. A. Harterager, A. M., State Hall, Albany, N. Y.

Adam HermanN, American Museum of Natural History, New York City.

William J. Holland, Ph. D., Carnegie Museum, Pittsburgh, Pa.

Arthur Hollick, Ph. D., New York Botanical Garden, Bronx Park, New York, N. $\mathbf{Y}$.

George H. Hudson, 19 Broad St., Plattsburgh, N. Y.

Louts Hussakof, Ph. D., American Museum of Natural History, New York, N. Y.

JEsse HyDE, School of Mines, Kingston, Ontario.

RoBert T. JACKson, S. D., 56 Bay State Road, Boston, Mass.

JoHN M. Jessur, Smithsonian Institution, Washington, D. C.

Edward M. Kindele, Ph. D., U. S. Geological Survey, Washington, D. C.

EDwin KIrK, Ph. D., U. S. Geological Survey, Washington, D. C.

Frank H. KNowlton, Ph. D., U. S. National Museum, Washington, D. C.

Lawrence M. Lambe, Geological Survey of Canada, Ottawa, Canada.

Frederic B. Loomis, Ph. D., Amherst College, Amherst, Mass.

Richard S. Lul., Ph. D., Yale University, New Haven. Conn.

D. D. Luther, Naples, N. Y.

VICTOR W. LxoN, C. E., Jeffersonville, Ind.

Thomas H. Macbride, Ph. D., University of Iowa, Iowa City, Iowa.

C. E. McCluna, Ph. D., University of Kansas, Lawrence, Kans.

J. H. McGregor, Ph. D., Columbla University, New York City.

Wendell O. Mansfield, B. S., U. S. Geological Survey, Washington, D. C.

George F. MatThew, Sc. D., 88 sumner St., St. John, N. B., Canada.

W. D. Matthew, Ph, D., American Museum of Natural History, New York, N. $Y$.

T. Poole MaYnarn, Ph. D., Atlanta, Ga.

John C. Merriam, Ph. D., University of California, Berkeley, Cal.

L. H. Mrzter, State Normal School, Los Angeles, Cal.

RoY L. Moodie, Ph. D., University of Kansas, Lawrence, Kans.

Wrrtiam C. MoRse, Ohio State University, Columbus, Ohio.

Henry F. Osborn, Sc. D., American Museum of Natural History, New York, N. $\mathbf{Y}$.

R. W. PACK, U. S. Geological Survey, Washington, D. C.

William A. Parks, Ph. D., University of Toronto, Toronto, Canada.

William Pateen, Ph. D., Dartmouth College, Hanover, N. H.

O. A. Peterson, Carnegie Museum, Pittsburgh, Pa.

Charles S. Prosser, M. S., Ohio State University, Columbus, Ohio.

Percy E. Raymond, Ph. D., Museum of Comparative Zoology, Cambridge, Mass.

W. H. Reen, B. S., University of Wyoming, Laramie, Wyo.

Ghester A. Reeds, Ph. D., Bryn Mawr College, Bryn Mawr, Pa.

E. S. Rrags, A. B., Field Museum of Natural History, Chicago, Ill.

Paud V. Roundy, U. S. Geological Survey, Washington, D. C.

Robert R. Rowley, High School, Louisiana, Mo.

Rudolf Ruedemand, Ph. D., State Hall, Albany, N. Y.

Fredertck W. Sardeson, Ph. D., University of Minnesota, Minneapolis, Minn. 
Thomas E. Savage, Ph. D., University of Illinois, Urbana, Ill. Charles Schuchert, Yale University, New Haven, Conn.

William B. ScotT, Ph. D., 56 Bayard Ave., Princeton, N. J.

Henry M. Seely, M. D., Middlebury College, Middlebury, Vt.

Eujas H. Selrards, Ph. D., Tallahassee, Fla.

Henry W. Shimer, Ph. D., Massachusetts Institute of Technology, Boston, Mass.

Wiluiam J. Sinclair, Ph. D., Princeton University, Princeton, N. J.

BuRnetT Smith, Ph. D., Syracuse University, Syracuse, N. Y.

J. Perrin Smith, Ph. D., Stanford University, Cal.

Frank Springer, Ph. B., U. S. National Museum, Washington, D. C.

Timothy W. Stanton, Ph. D., U. S. National Museum, Washington, D. C.

Trmothy W. Stanton, B. S., U. S. National Museum, Washington, D. C.

Cunton R. Stauffer, Ph. D., Western Reserve University, Cleveland, Ohio.

Chartas H. Steranberg, 617 Vermont St., Lawrence, Kans.

Charles K. Swartz, Ph. D., Johns Hopkins University, Baltimore, Md.

Mignon Talbot, Ph. D., Mt. Holyoke College, South Hadley, Mass.

Edgar E. Teller, 3321 Sycamore St., Milwaukee, Wis.

ALbert Thompson, American Museum of Natural History, New York City.

William H. Twenhomer, B. S., University of Kansas, Lawrence, Kans.

EDward O. Ulatch, D. Sc., U. S. Geological Survey, Washington, D. C.

JaCOB VAN DeIoo, State Hall, Albany, New York.

Girbert van Ingen, Princeton University, Princeton, N. J.

T. Wayland Vaughan, Ph. D.. U. S. Geological Survey, Washington, D. C.

ANThoNy W. Vogdes, 2425 First St., San Diego, Cal.

Oharles D. Walcotr, LL. D., Smithsonian Institution, Washington, D. C.

Stuafer Welleg, Ph. D., University of Chicago, Chicago, Ill.

David WhIte, B. S., U. S. National Museum, Washington, D. C.

G. R. Wimuand, Ph. D., Yale University Museum, New Haven, Conn.

Hengr S. Wriliams, Ph. D., Cornell University, Ithaca, N. Y.

Samugt W. Wiluiston, Ph. D., University of Chicago, Chicago, Ill.

John D. Wirson, Syracuse University, Syracuse, N. Y.

Euvira Woon, Ph. D., Museum of Comparative Zoölogy, Harvard University, Cambridge, Mass.

\section{MEMBERS DECEASED}

Samuet Calvin. Died April 17, 1911.

RoBert H. GordoN. Died May 10, 1910.

\section{MEMBERS-ELECT, DECEMBER S1, 1911}

HaRvey BassukR, Johns Hopkins University, Baltimore, Ma.

Charties ButTs, U. S. Geological survey, Washington, D. C.

Wrrt E. Crane, Swissvale P. O., Pittsburgh, Pa.

Julia A. GARDNER, Johns Hopkins University, Baltimore, Md.

F. C. Greene, Geological Survey of Missouri, Rolla, Mo.

B. C. Jefreter, Harvard University, Cambridge, Mass.

Clara G. Mark, Ohio State University, Westerville, Ohlo.

MaURice G. MenL, University of Chicago, Chicago, Ill.

Rector D. Mosler, U. S. Geological Survey, Washington, D. C.

JaMes E. Narraway, Ottawa, Canada.

HerRICK E. Wilson, University of Chicago, Chicago, Ill.

William J. Wilson, Geological Survey of Canada, Ottawa, Canada. 